doi: 10.18484/2305-0047.2017.2.155

\author{
A.I. RADCHENKO, A.G. ZHUKOVEC, Y.M. BOGDAEV
}

\title{
OSTEOSYNTHESIS IN SURGICAL TREATMENT OF METASTATIC LESIONS OF LONG TUBULAR BONES
}

\author{
SE "Republican Scientific and Practical Center of Oncology \\ and Medical Radiology Named after N.N.Alexandrov", Minsk, \\ The Republic of Belarus
}

Цель. Изучить причины и факторы риска развития осложнений, требующих выполнения ревизионных операций после интрамедуллярного и накостного остеосинтеза длинных трубчатых костей, пораженных метастазами.

Материал и методы. Ретроспективно были проанализированы результаты хирургического лечения 44 пациентов по поводу метастазов в длинных трубчатых костях. У 12 пациентов имело место солитарное поражение костей скелета, у 11 - множественное, у 21 - костные метастазы сочетались с метастатическим поражением внутренних органов. У 35 пациентов был установлен патологический перелом, у 9 - угроза патологического перелома. Интрамедуллярный остеосинтез был выполнен в 34 случаях, накостный остеосинтез - в 3 случаях, интрамедуллярный остеосинтез в комбинации с аллопластикой - в 12 случаях.

Результаты. Применение ОС при лечении метастазов злокачественных опухолей в длинных трубчатых костях позволило сохранить функцию конечности в 75,0\% случаев, еще в 14,6\% наблюдений была выполнена ревизионная органосохраняющая операция, не удалось восстановить функцию конечности в 10,4\% случаев. 13 осложнений потребовали выполнения ревизионной операции. Медиана времени до развития этих осложнений составила 6 месяцев (диапазон 1-12 месяцев). Причинами осложнений стали местное прогрессирование опухоли, отсутствие консолидации и нарушение целостности конструкции. Факторы риска развития осложнений, требующих выполнения ревизионной операции: патологический перелом $(\mathrm{p}=0,046)$, продолженный рост рака почки $(\mathrm{p}=0,013)$ и лучевая терапия, проводимая перед хирургическим лечением $(\mathrm{p}=0,029)$. У пациентов с лучшим прогнозом для жизни осложнения, связанные с нарушением целостности металлоконструкции или фиксации кости, развиваются при более длительной и активной нагрузке на конечность.

Заключение. Остеосинтез является оптимальным методом хирургического лечения костных метастазов в определенных клинических ситуациях. При одиночных метастазах радиорезистентных опухолей и контролируемом опухолевом процессе более обоснованным является радикальное хирургическое удаление метастаза с устранением дефекта кости аллотрансплантатом или эндопротезом.

Ключевые слова: метастазы, длинные трубчатые кости, остеосинтез, радикальное хирургическое удаление, нарушение целостности конструкции, осложнения, смертность

Objectives. This study was designed to investigate the causes and risk factors of complications requiring revision surgeries after intramedullary and plate osteosynthesis of the long tubular bones affected by metastases.

Methods. Surgical treatment outcomes of patients with long tubular bones metastases $(n=44)$ were analyzed retrospectively. Twelve patients had solitary skeletal metastasis, eleven - multiple, twenty one - bone metastases combined with visceral metastases. The pathological fracture was diagnosed in 35 patients and the threat of the pathological fracture - in 9. Intramedullary osteosynthesis was carried out in 34 cases, plate osteosynthesis - in 3 cases, intramedullary osteosynthesis with alloplasty - in 12 cases.

Results. Application of OS in the metastatic treatment of malignant tumors in long tubular bones have allowed saving the extremity function in $75 \%$ cases; the revision organ-saving surgery was carried out in $14,6 \%$ observations; restoration of the extremity function was failed in $10,4 \%$ cases. Thirteen complications caused by bone metastases required the revision surgery. Median time was 6 months (range of 1-12 months). The causes of complications included local tumor progression, the absence of osseous consolidation and violation of the structural integrity. Risk factors of complications development which require the revision surgeries were the following: pathologic fracture $(p=0,046)$, progressive renal cell carcinoma $(p=0,013)$ and radiation therapy before surgery $(p=0,029)$. In patients with the best life prognosis the complications related with violation of the metal construction integrity or bone fixation failure have developed in longer and active load on the extremity.

Conclusion. Osteosynthesis appears to be an efficient method in the treatment of metastatic bone disease in the specific clinical cases. Radical surgical removal of the metastases with the elimination of the bone defect by allograft or endoprosthesis is more reasonable in case of solitary metastases of radio-resistant tumors and controlled tumor process.

Keywords: metastases, long tubular bones, osteosynthesis, radical surgical removal, bone fixation failure, complications, mortality 
Novosti Khirurgii. 2017 Mar-Apr; Vol 25 (2): 155-162

Osteosynthesis in Surgical Treatment of Metastatic Lesions of Long Tubular Bones

A.I. Radchenko, A.G. Zhukovec, J.M. Bogdaev

\section{Introduction}

Witnin recent years advances in modern oncology have led to the prolonged survival of more patients with cancer which has resulted in increasing numbers of individuals with metastatic bone disease. Skeleton is the third most common site of metastatic disease behind lung and liver [1].

The skeleton is the most common site to be affected by metastatic cancer of breast, kidney, prostate, lung and thyroid gland. Thus, at necropsy of prostate and brest cancer patients the metastases in bones are detected in more than $70 \%$; in the lung cancer, kidney cancer and thyroid cancer - in $35-42 \%$ of cases [2].

To underline the importance of the problem of bone metastases demonstrates the amount of funds allocated for the treatment. For example, overall management of metastatic bone disease is estimated to result as much as $17 \%$ of the total direct medical costs of cancer treatment in the United States [3].

The treatment of choice of metastatic lesions of long tubular bones should be based on a location of metastatic focus, extent of bone destruction, the presence of pathologic fracture, nosological form of a tumor as well as the degree of functional limb impairment and the patient's expectations. Nowadays there have been only a few reports concerning the development of surgical treatment options for management of bone metastasis $[4,5]$. In this regard, surgical treatment of metastatic bone disease is performed on the general principles underlying the management of oncology and traumatology and often - on surgeon's preference.

Surgical treatment of skeletal metastatic lesions has performed through use of both methods: endoprosthesis and osteosynthesis.

The apparent advantage of endoprosthesis consists in the radical excision of metastases with simultaneous restoration of supporting gait abilities in lower limbs regardless of the volume of bone destruction and presence of soft tissue tumor component; and also there is a low risk of structural integrity violations. These procedures have many disadvantages, such as increasing hospitalization and traumatic character of the surgery (the resection of articular bone division results in abundant blood loss, muscles cut-off which are repaired with sutures to the endoprosthesis). It should be also mentined about a high cost of implants [6].

The use of intramedullary osteosynthesis
(IOS) with reconstructive nails has a number of advantages. As a rule, the introduction of intramedullary nail is closed, which greatly reduces a surgical trauma and the blood loss [7]. However, the full restoration of supporting ability of the limb in this case depends much on the consolidation in the fracture zone - if consolidation does not occur a fracture or migration of the device is almost inevitable [7]. Furthermore, the use of IOS for a pathological fracture fixation due to metastasis as a rule does not imply the removal of the tumor focus.

The advantage of the plate extramedullary osteosynthesis (EOS) is the ability to perform curettage of a metastasis and to consolidate adequately the bone fragments under visual control. Disadvantages of this method include a greater volume and duration of the surgical intervention, less reliability of the entire bone fixation [8].

The present study analyzes the results of osteosynthesis of long tubular bones affected by metastasis, to identify the clinical situations in which OS is considered to be the best method of bone stabilization, as well as the situations when the other methods of reconstruction should be choosed.

Objectives. To study the causes and risk factors of complications development, requiring revision surgeries after intramedullary and extramedullary osteosynthesis of the long tubular bones affected by metastases.

\section{Methods}

Surgical treatment results of patients $(\mathrm{n}=44,17$ men and 27 women, 2003-2016 yrs.) with metastatic long tubular bone tumors underwent osteosynthesis in SE "N.N. Alexandrov National Cancer Centre of Belarus for Oncology and Medical Radiology" were retrospectively analyzed. The average age of patients was 58 years. A total of 49 surgeries were performed, $40-$ due to pathological fractures, $9-$ due to the threat of pathologic fracture. The information concerning location of metastases and methods of osteosynthesis in patients with different morphological forms of tumors are presented in Tables 1, 2.

Tumor process manifested by bone metastasis occurred in 18 patients.

In other observations, the median time of bone metastases development after identifying the primary tumor made up 20 months (the range of 
Structure of surgical interventions

Table 1

\begin{tabular}{lcccc}
\hline \multicolumn{1}{c}{ Nosology } & IOS & Method of reconstruction & Total \\
& 10 & 1 & 8 & 19 \\
\hline Renal cancer (RC) & 15 & 1 & - & 16 \\
Breast cancer (BC) & 5 & 1 & 1 & 7 \\
Lung cancer (LC) & 2 & - & 1 & 3 \\
Colon cancer (CC) & 2 & - & - & 2 \\
Sarcoma of soft tissues & - & - & 1 & 1 \\
Melanoma & - & - & 1 & 1 \\
Uterine carcinosarcoma & 34 & 3 & 12 & 49 \\
Total & & & \\
\hline
\end{tabular}

3-215 months). In 21 cases bone metastases were combined with visceral metastases. A solitary lesion of skeletal bones occured in 12 patients, multiple in 11 .

In 12 of 40 cases, a pathological fracture developed against conservative management; in the rest cases it was the first manifestation of a tumor process or the first manifestation of disease progression.

Radiotherapy (RT) for bone metastases was performed in $20(45,5 \%)$ patients, prior to surgery in $9(20,5 \%)$ of patients, after osteosynthesis in $11(25,0 \%)$ of patients. Systemic treatment in the incisional period depended on histological forms of cancer, the prevalence of tumor and the patient's general condition. The starting point for assessing the results of study was the date of installation of the metal device and the final event - the date of death and date of complications leading to loss of limb function, requiring the reoperation.

The Test $\chi^{2}$ Pearson or Fisher's exact test (depending on the requirements of each test) were used for statistical analysis to identify the factors influencing the final result. The analysis of differences in the course of survival was made by a Kaplan-Meier survival plot. Differences at the level of $p<0,05$ were considered statistically significant.

\section{Results}

The performance of osteosynthesis allowed maintaining or restoring the function of limbs in $75.0 \%$ of cases.

Local postoperative complications developed in $17(34,7 \%)$ cases after OS. The revision surgery was required in $13(26,5 \%)$ cases. The complications associated with healing of surgical wounds were treated effectively with nonsurgical modalities in 4 patients.

The causes for reoperations: further growth of the tumor in the area of the fracture $(n=5)$, suppuration in the allograft area $(n=2)$, pathological bone fracture in the distal portion of the intramedullary nail $(n=1)$, failure of fixation against the absence of osseous consolidation $(n=3)$, and against the tumor progression $(n=2)$. The median time was 6.6 months (range of 1-12 months).

The most significant risk factors for complications (Table 4) were a pathological fracture $(p=0,046)$, the tumor progression associated with non-radical removal of renal carcinoma metastasis $(\mathrm{P}=0,013)$, the radiation therapy prior to the development of pathological fracture (breast cancer) $(\mathrm{p}=0,029)$.

In comparing the survival rate of patients, depending on the complications, requiring reoperations, significant differences were established (plog-rank=0.004). (Fig.) Survival median time for

Location of metastasis

Table 2

\begin{tabular}{lc}
\hline \multicolumn{1}{c}{ Location } & Number, \% \\
\hline Upper third of the femur & $18(37,5 \%)$ \\
Intertrochanteric region, neck and head of the femur & $8(16,7)$ \\
Subtrochanteric region of the femur & $10(20,8)$ \\
Femoral shaft & $13(27,1)$ \\
Lower third of the femur & $4(8,3)$ \\
Upper third of the humerus & $1(2,1)$ \\
& $9(18,7)$ \\
Upper third of the tibia & $1(2,1)$ \\
Middle third of the tibia & $2(4,2)$ \\
Total & $48(100 \%)$ \\
\hline
\end{tabular}


Characteristics of patients requiring reoperation

\begin{tabular}{|c|c|c|c|c|c|c|}
\hline № & $\begin{array}{l}\text { Primary } \\
\text { tumor }\end{array}$ & $\begin{array}{l}\text { Location of } \\
\text { metastasis }\end{array}$ & $\begin{array}{c}\text { Type of } \\
\text { osteosynthesis }\end{array}$ & $\begin{array}{l}\text { Indications for } \\
\text { reoperation }\end{array}$ & $\begin{array}{c}\text { Surgical } \\
\text { interventions }\end{array}$ & $\begin{array}{l}\text { Time till the } \\
\text { revision, } \\
\text { months }\end{array}$ \\
\hline 1 & $\begin{array}{r}\text { Renal } \\
\text { cancer }\end{array}$ & $\begin{array}{l}\text { upper third of the } \\
\text { humerus }\end{array}$ & intramedullary & Continued growth & endoprosthesis & 12 \\
\hline 2 & $\begin{array}{l}\text { Renal } \\
\text { cancer }\end{array}$ & $\begin{array}{l}\text { middle/lower } \\
\text { third of the femur }\end{array}$ & intramedullary & Continued growth & endoprosthesis & 12 \\
\hline 3 & $\begin{array}{l}\text { Breast } \\
\text { cancer }\end{array}$ & $\begin{array}{l}\text { lower third of the } \\
\text { femur }\end{array}$ & $\begin{array}{l}\text { extramedullary } \\
\text { (with plate) }\end{array}$ & $\begin{array}{l}\text { Fracture of plate }+ \\
\text { absence of fracture } \\
\text { consolidation }\end{array}$ & $\begin{array}{l}\text { Nothing due to } \\
\text { disease progression }\end{array}$ & 1 \\
\hline 4 & $\begin{array}{l}\text { Breast } \\
\text { cancer }\end{array}$ & $\begin{array}{l}\text { middle/lower } \\
\text { third of the femur }\end{array}$ & intramedullary & $\begin{array}{l}\text { Fracture of nail + } \\
\text { absence of fracture } \\
\text { consolidation }\end{array}$ & endoprosthesis & 5 \\
\hline 5 & Melanoma & $\begin{array}{l}\text { middle third of } \\
\text { the humerus }\end{array}$ & $\begin{array}{l}\text { intramedullary } \\
+ \text { resection }+ \\
\text { alloplasty }\end{array}$ & suppuration & $\begin{array}{l}\text { Autoplasty with } \\
\text { diaphysis of the } \\
\text { fibula }\end{array}$ & 2,5 \\
\hline 6 & $\begin{array}{l}\text { Breast } \\
\text { cancer }\end{array}$ & $\begin{array}{l}\text { upper/middle } \\
\text { third of the femur }\end{array}$ & intramedullary & $\begin{array}{l}\text { Pathological fracture } \\
\text { in the lower third } \\
\text { of the femur ( } 2^{\text {nd }} \\
\text { metastasis) }\end{array}$ & $\begin{array}{l}\text { Nothing due to } \\
\text { disease progression }\end{array}$ & 8 \\
\hline 7 & $\begin{array}{l}\text { Lung } \\
\text { cancer }\end{array}$ & $\begin{array}{l}\text { upper/middle } \\
\text { third of the femur }\end{array}$ & $\begin{array}{l}\text { extramedullary } \\
\text { (with plate) }\end{array}$ & Continued growth & $\begin{array}{c}\text { Resection + } \\
\text { alloplasty + EOS }\end{array}$ & 6 \\
\hline 8 & $\begin{array}{l}\text { Lung } \\
\text { cancer }\end{array}$ & $\begin{array}{l}\text { upper/middle } \\
\text { third of the femur }\end{array}$ & $\begin{array}{l}\text { Intramedullary } \\
+ \text { resection }+ \\
\text { alloplasty }\end{array}$ & suppuration & $\begin{array}{l}\text { disarticulation of } \\
\text { the limb }\end{array}$ & 5 \\
\hline 9 & $\begin{array}{l}\text { Breast } \\
\text { cancer }\end{array}$ & $\begin{array}{l}\text { middle third of } \\
\text { the tibia }\end{array}$ & intramedullary & $\begin{array}{l}\text { absence of fracture } \\
\text { consolidation } \\
+ \text { fracture of screws }\end{array}$ & $\begin{array}{l}\text { Nothing due to } \\
\text { disease progression }\end{array}$ & 12 \\
\hline 10 & $\begin{array}{r}\text { Renal } \\
\text { cancer }\end{array}$ & $\begin{array}{l}\text { upper third of the } \\
\text { femur }\end{array}$ & $\begin{array}{l}\text { extramedullary } \\
\text { (with plate) }\end{array}$ & $\begin{array}{l}\text { Continued growth } \\
+ \text { fracture of plate }\end{array}$ & endoprosthesis & 10 \\
\hline 11 & $\begin{array}{l}\text { Colon } \\
\text { cancer }\end{array}$ & $\begin{array}{l}\text { upper third of the } \\
\text { femur }\end{array}$ & intramedullary & $\begin{array}{l}\text { Continued growth }+ \\
\text { fracture }\end{array}$ & endoprosthesis & 3 \\
\hline 12 & $\begin{array}{l}\text { Renal } \\
\text { cancer }\end{array}$ & $\begin{array}{l}\text { upper third of the } \\
\text { femur }\end{array}$ & intramedullary & Continued growth & endoprosthesis & 4 \\
\hline 13 & $\begin{array}{r}\text { Renal } \\
\text { cancer }\end{array}$ & $\begin{array}{l}\text { upper third of the } \\
\text { femur }\end{array}$ & intramedullary & Continued growth & $\begin{array}{l}\text { Nothing due to } \\
\text { disease progression }\end{array}$ & 11 \\
\hline
\end{tabular}

patients with recurrent impairment of the function of a limb was 39,8 months and for patients without this kind of complications - 13,8 months (plogrank $=0,004)$. This indicates that the complications associated with failure of fixation in the patients with a better life prognosis, develop in the case of longer and more active load on the limb.

\section{Discussion}

The main objective of palliative surgical treatment of metastases in the long tubular bones is to stabilize bone that is weak or broken, limb function restoring and the creation of the possibility of continuing adequate anti-tumor therapy. In total the results of surgical treatment of patients with bone metastases using OS are considered to be satisfactory and acceptable in the case to preserve or to restore the integrity of the bone in short terms favorably affected the quality of patients' life. The use of different options for osteosynthesis is more preferable in patients with lesion usually occurs in the metaphyseal or diaphyseal regions of the long bones. A complication rate requiring replacement of the fixing construction in those patients was

Fig. Survival rate of patients, depending on the presence of complications, requiring reoperation

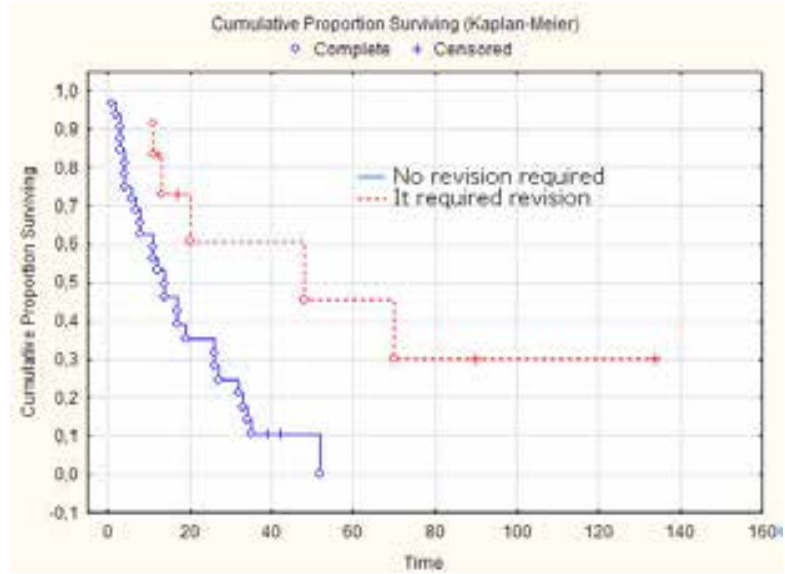


Risk factors for the development of local complications

\begin{tabular}{|c|c|c|c|}
\hline \multirow[t]{2}{*}{ Factor } & \multicolumn{2}{|c|}{ Number } & \multirow{2}{*}{$\begin{array}{c}\text { Value } \mathrm{p}\left(\chi^{2}-\text { Pearson }\right. \\
\text { Fisher's exacttest }) \\
\end{array}$} \\
\hline & No revision required & Revision required & \\
\hline Sex & & & \\
\hline Men & & 6 & 0,22 \\
\hline Women & & 7 & \\
\hline Age & & & \\
\hline Average (range) & 59,3 & 57 & 0,82 \\
\hline Median & $58,0(9,7)$ & $58,5(11,0)$ & \\
\hline Location & & & \\
\hline Upper limb & 8 & 2 & 0,6 \\
\hline Lower limb & 28 & 11 & \\
\hline Nosology & & & \\
\hline Renal cancer & 14 & 5 & 0,68 \\
\hline Breast cancer & 12 & 4 & 0,24 \\
\hline Lung cancer & 5 & 2 & 0,16 \\
\hline Others & 5 & 2 & 0,16 \\
\hline Pathological fracture & & & \\
\hline 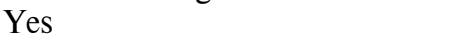 & 27 & 13 & $0,046^{*}$ \\
\hline No & 9 & 0 & \\
\hline Metastasis removal & & & \\
\hline 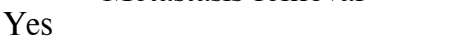 & 13 & 1 & 0,052 \\
\hline Нет & 23 & 12 & \\
\hline $\mathrm{BC}+$ radiotherapy before & & & \\
\hline Yes & 2 & 3 & $0,029^{*}$ \\
\hline No & 10 & 1 & \\
\hline Radiotherapy after surgery & & & \\
\hline Yes & 8 & 3 & 0,84 \\
\hline No & 41 & 10 & \\
\hline $\mathrm{RC}$ without metastasis removal & 5 & 5 & $0,013^{*}$ \\
\hline
\end{tabular}

$26,5 \%$, which is comparable with the results of other authors [9]. Tumor control is generally accomplished by postoperative radiation therapy, which is also effective in treating pain caused by bone metastasis [10].

The main reasons requiring reoperation after the OS is appeared to be a further growth of metastatic tumor, an absence of osseous consolidation of a fracture, a failure of fixation. [9].

Further growth of the tumor was the cause of re-intervention in 5 patients with renal cancer (RC), and in 1 - with lung cancer (LC). It is known that RC metastases are chemo- and radioresistant and often do not stopping metastases at their source, despite the performed treatment [11]. Use of targeted therapy in the treatment of disseminated RC can significantly extend the life of a considerable number of patients; however, its efficacy in the bone metastasis is slightly lower in comparison with visceral metastases [12]. In this regard, use of OS in this group of patients is more justified to preserve the quality of life in this disease progression.

Complications were not observed after the preventive surgery, indicating the negative effect of a pathological fracture on the final functional outcome. The frequency rate of pathological fractures after irradiation varies from $8 \%$ to $11 \%$ and successful surgical treatment requires radical resection of the irradiated bone segment [13].

In this study in patients with breast cancer $(n=5)$, when a pathological fracture was preceded by radiotherapy (RT), complications requiring the revision surgery developed in 3 cases.

Thus, in case of detection of metastatic lesions in long tubular bones before decision to include radiation therapy is necessary to assess the probability of a fracture, particularly in patients with a controlled tumor process.

It is necessary to use greater the special scales (Mirels' classification for impending pathological fracture and Harrington criteria) at high risk of pathological fracture and should undergo prophylactic internal fixation (surgical stabilization of bone) prior to radiotherapy conduction [14].

The other of the major complications of OS is the failure of fracture consolidation significantly increasing the risk of fixation device fracture against the sustained load [15]. In this study, there were 2 cases of fractures of the intramedullary nail and 2 cases of fractures of the extramedullary plate. Failure of fixation was observed in $5(10.2 \%)$ cases: in case of further growth of the tumor 
( 2 cases of RC), and failure fracture consolidation against the preoperative radiotherapy ( 3 cases of $\mathrm{BC}$ ). According to the literature data, the frequency of these complications varies from 2.2 to $10.8 \%[8,9]$.

Most often the failure of consolidation after the OS with intramedullary nail or extramedullary plate is observed in radio- and chemoresistant tumors.

The suppuration $(16,7 \%)$ in the allograft area was a singe complication in this case. In total, the frequency rate of this complication is observed from $16,7 \%$ to $63,7 \%$ of cases $[16,17]$.

Currently, the preferred method of treatment of metastatic lesions of long bones use segmental resection with endoprosthetics, intramedullary osteosynthesis by means of locking reconstruction nail.

Thus, osteosynthesis is thought to be the best method of surgical treatment of metastatic lesions of long tubular bones. It is difficult to overestimate a simple, minimally invasive method of treatment of bone metastases in the advanced cancer. However, in case of massive bone and soft tissue lesion as well as in metastases location in the metaepiphyseal zones, OS is not considered to be an optimal reconstruction method.

\section{Conclusions}

1. Using methods of osteosynthesis in metastatic lesions of long bones restored the function of support ability of the limbs in 75,0\% of cases; the revision organ-saving surgery was performed in $14,6 \%$ of cases; failure to restore limb function - in $10,4 \%$ of cases.

2. The main factors affecting the frequency rate of reoperations after osteosynthesis are as follows: the presence of a pathological fracture $(p=0,046)$, further growth of the tumor due to non-radical removal of renal cancer metastasis $(\mathrm{P}=0,013)$ and conducting the radiation therapy prior to the development of a pathological fracture $(\mathrm{p}=0,029)$.

3. Improvement of osteosynthesis functional outcome is anable in the case of preventive operations performance prior to radiotherapy considering risk factors of pathological fracture development, especially in the location of metastases in the long tubular bones of the lower limbs.

4. In case of solitary metastases of radioresistant tumors and controlled tumor process the treatment of metastatic lesions of long bones use segmental resection with an allograft or endoprosthetics.

The work was performed in accordance with the

\section{Research Plan of SE "N.N. Alexandrov National Cancer Centre of Belarus for Oncology and Medical Radiology".}

\section{ЛИТЕРАТУРА}

1. Weber KL, Randall RL, Grossman S, Parvizi J. Management of lower-extremity bone metastasis. $J$ Bone Joint Surg Am. 2006 Dec;88(Suppl 4):11-9.

2. Coleman RE. Clinical features of metastatic bone disease and risk of skeletal morbidity. Clin Cancer Res. 2006 Oct 15;12(20 Pt 2):6243s-49s.

3. Schulman KL, Kohles J. Economic burden of metastatic bone disease in the U.S. Cancer. 2007 Jun $1 ; 109(11): 2334-42$.

4. Ruggieri P, Mavrogenis AF, Casadei R, Errani $\mathrm{C}$, Angelini A, Calabrt T, et al. Protocol of surgical treatment of long bone pathological fractures. Injury. 2010 Nov;41(11):1161-67. doi: 10.1016/j.injury.2010.09.018.

5. Willeumier JJ, van der Linden YM, van de Sande MAJ, Dijkstra PDS. Treatment of pathological fractures of the long bones. EFORT Open Rev. 2016 May;1:136-45. doi: 10.1302/2058-5241.1.000008.

6. Wedin R, Bauer HC. Surgical treatment of skeletal metastatic lesions of the proximal femur: endoprosthesis or reconstruction nail? J Bone Joint Surg Br. 2005 Dec;87(12):1653-57.

7. Sarahrudi K, Hora K, Heinz T, Millington S, Vйсsei V. Treatment results of pathological fractures of the long bones: a retrospective analysis of 88 patients. Int Orthop. 2006 Dec; 30(6):519-24. doi: 10.1007/s00264-006-0205-9.

8. Hunt KJ, Gollogly S, Randall RL. Surgical fixation of pathologic fractures: an evaluation of evolving treatment methods. Bull Hosp Jt Dis. 2006;63(3-4):7782.

9. Miller BJ, Soni EE, Gibbs CP, Scarborough MT. Intramedullary nails for long bone metastases: why do they fail? Orthopedics. 2011 Apr 11;34(4):274. doi: 10.3928/01477447-20110228-12.

10. Janjan NA. Radiation for bone metastases: conventional techniques and the role of systemic radiopharmaceuticals. Cancer. 1997 Oct 15;80(8 Suppl):1628-45.

11. Althausen P, Althausen A, Jennings LC, Mankin HJ. Prognostic factors and surgical treatment of osseous metastases secondary to renal cell carcinoma. Cancer. 1997 Sep 15;80(6):1103-9. doi: 10.1002/ (SICI) 1097-0142(19970915)80:6<1103.

12. ZołnierekJ, Nurzyński P, Langiewicz $P$, Oborska S, Waśko-Grabowska A, Kuszatal E, et al. Efficacy of targeted therapy in patients with renal cell carcinoma with pre-existing or new bone metastases. $J$ Cancer Res Clin Oncol. 2010 Mar;136(3):371-78. doi: 10.1007/s00432-009-0664-7.

13. Frassica DA. General principles of external beam radiation therapy for skeletal metastases. Clin Orthop Relat Res. 2003 Oct;(415 Suppl):S158-64.

14. Mirels $\mathrm{H}$. Metastatic disease in long bones. A proposed scoring system for diagnosing impending pathologic fractures. Clin Orthop Relat Res. 1989 Dec;(249):256-64.

15. Brumback RJ, Toal TR Jr, Murphy-Zane MS, Novak VP, Belkoff SM. Immediate weight-bearing after treatment of a comminuted fracture of the femoral shaft with a statically locked intramedullary nail. 
J Bone Joint Surg Am. 1999 Nov;81(11):1538-44.

16. Qu Huayi, Guo Wei, Yang Rongli, Li Dasen, Tang Shun, Yang Yi, et al. Reconstruction of segmental bone defect of long bones after tumor resection by devitalized tumor-bearing bone. World J Surg Oncol. 2015;13:282. doi: 10.1186/s12957-015-06943 .

17. Ahlmann ER, Menendez LR. Intercalary endoprosthetic reconstruction for diaphyseal bone tumours. J Bone Joint Surg [Br]. 2006 Nov;88-B(11):1487-91. doi:10.1302/0301-620X.88B11.

\section{REFERENCES}

1. Weber KL, Randall RL, Grossman S, Parvizi J. Management of lower-extremity bone metastasis. $J$ Bone Joint Surg Am. 2006 Dec;88(Suppl 4):11-9.

2. Coleman RE. Clinical features of metastatic bone disease and risk of skeletal morbidity. Clin Cancer Res. 2006 Oct 15;12(20 Pt 2):6243s-49s.

3. Schulman KL, Kohles J. Economic burden of metastatic bone disease in the U.S. Cancer. 2007 Jun $1 ; 109(11): 2334-42$.

4. Ruggieri P, Mavrogenis AF, Casadei R, Errani $C$, Angelini A, Calabrt $T$, et al. Protocol of surgical treatment of long bone pathological fractures. Injury. 2010 Nov;41(11):1161-67. doi: 10.1016/j.injury.2010.09.018.

5. Willeumier JJ, van der Linden YM, van de Sande MAJ, Dijkstra PDS. Treatment of pathological fractures of the long bones. EFORT Open Rev. 2016 May;1:136-45. doi: 10.1302/2058-5241.1.000008.

6 . Wedin R, Bauer HC. Surgical treatment of skeletal metastatic lesions of the proximal femur: endoprosthesis or reconstruction nail? J Bone Joint Surg Br. 2005 Dec;87(12):1653-57.

7. Sarahrudi K, Hora K, Heinz T, Millington S, Vйcsei V. Treatment results of pathological fractures of the long bones: a retrospective analysis of 88 patients. Int Orthop. 2006 Dec; 30(6):519-24. doi: 10.1007/s00264-006-0205-9.

8. Hunt KJ, Gollogly S, Randall RL. Surgical fixation of pathologic fractures: an evaluation of evolving

\section{Адрес для корреспонденции}

223040, Республика Беларусь,

Минский район, пос. Лесной,

ГУ «Республиканский научно-практический

центр онкологии и медицинской

радиологии им. Н.Н. Александрова»,

лаборатория онкопатологии

центральной нервной системы

с группой онкопатологии головы и шеи,

тел.моб.: +375447724255,

e-mail: Aradchenko@mail.ru,

Радченко Артем Игоревич

\section{Сведения об авторах}

Радченко А.И., научный сотрудник лаборатории онкопатологии центральной нервной системы с группой онкопатологии головы и шеи ГУ «Республиканский научно-практический центр онкологии и медицинской радиологии им. Н.Н. Александрова». Жуковец А.Г., к.м.н., руководитель лаборатории онкопатологии центральной нервной системы с treatment methods. Bull Hosp Jt Dis. 2006;63(3-4):7782.

9. Miller BJ, Soni EE, Gibbs CP, Scarborough MT. Intramedullary nails for long bone metastases: why do they fail? Orthopedics. 2011 Apr 11;34(4):274. doi: 10.3928/01477447-20110228-12.

10. Janjan NA. Radiation for bone metastases: conventional techniques and the role of systemic radiopharmaceuticals. Cancer. 1997 Oct 15;80(8 Suppl):1628-45.

11. Althausen P, Althausen A, Jennings LC, Mankin HJ. Prognostic factors and surgical treatment of osseous metastases secondary to renal cell carcinoma. Cancer. 1997 Sep 15;80(6):1103-9. doi: 10.1002/ (SICI)1097-0142(19970915)80:6<1103.

12. ZołnierekJ, Nurzyński P, Langiewicz $P$, Oborska S, Waśko-Grabowska A, Kuszatal E, et al. Efficacy of targeted therapy in patients with renal cell carcinoma with pre-existing or new bone metastases. $J$ Cancer Res Clin Oncol. 2010 Mar;136(3):371-78. doi: 10.1007/s00432-009-0664-7.

13. Frassica DA. General principles of external beam radiation therapy for skeletal metastases. Clin Orthop Relat Res. 2003 Oct;(415 Suppl):S158-64.

14. Mirels H. Metastatic disease in long bones. A proposed scoring system for diagnosing impending pathologic fractures. Clin Orthop Relat Res. 1989 Dec;(249):256-64.

15. Brumback RJ, Toal TR Jr, Murphy-Zane MS, Novak VP, Belkoff SM. Immediate weight-bearing after treatment of a comminuted fracture of the femoral shaft with a statically locked intramedullary nail. J Bone Joint Surg Am. 1999 Nov;81(11):1538-44.

16. Qu Huayi, Guo Wei, Yang Rongli, Li Dasen, Tang Shun, Yang Yi, et al. Reconstruction of segmental bone defect of long bones after tumor resection by devitalized tumor-bearing bone. World $J$ Surg Oncol. 2015;13:282. doi: 10.1186/s12957-0150694-3.

17. Ahlmann ER, Menendez LR. Intercalary endoprosthetic reconstruction for diaphyseal bone tumours. J Bone Joint Surg [Br]. 2006 Nov;88-B(11):1487-91. doi:10.1302/0301-620X.88B11.

\section{Address for correspondence}

223040, Republic of Belarus, Minsk

region, Lesnoy settl.,

EE «N.N. Alexandrov National Cancer Centre

of Belarus for Oncology and Medical Radiology».

Laboratory of oncological pathology

of the central nervous system with a group

of oncological pathology of the head and neck,

Tel.: 375447724255

e-mail: Aradchenko@mail.ru

Artem I. Radchenko

\section{Information about the authors}

Radchenko A.I. Researcher of laboratory of oncopathology of the central nervous system with the group of oncopathology of the head and neck, SE «N.N. Alexandrov National Cancer Centre of Belarus for Oncology and Medical Radiology».

Zhukovec A.G. PhD, Head of laboratory of oncopathology of the central nervous system with the 
группой онкопатологии головы и шеи ГУ «Республиканский научно-практический центр онкологии и медицинской радиологии им. Н.Н. Александрова». Богдаев Ю.М., к.м.н., заведующий отделением реконструктивно-восстановительной хирургии ГУ «Республиканский научно-практический центр онкологии и медицинской радиологии им. Н.Н. Александрова».

\section{Информация о статье}

Поступила 18 ноября 2016 г.

Принята в печать 9 января 2017 г.

Доступна на сайте 28 марта 2017 group of oncopathology of the head and neck, SE «N.N. Alexandrov National Cancer Centre of Belarus for Oncology and Medical Radiology».

Bogdaev Y.M. PhD, Head of department of reconstructive and restorative surgery, $\mathrm{SE} \ll \mathrm{N} . \mathrm{N}$. Alexandrov National Cancer Centre of Belarus for Oncology and Medical Radiology».

\section{Article history}

Recieved 18 November 2016

Accepted 9 January 2017

Available online 28 March 2017 